\title{
Association Between Exposure to Mass Media Family Planning Messages and Utilization of Modern Contraceptive Among Urban and Rural Youth Women in Ethiopia
}

This article was published in the following Dove Press journal:

International Journal of Women's Health

\author{
Mohammed Ahmed (ID) \\ Abdu Seid (D) ${ }^{2}$ \\ 'Department of Public Health, College of \\ Health Science, Woldia University, \\ Woldia, Ethiopia; ${ }^{2}$ Department of \\ Midwifery, College of Health Science, \\ Woldia University, Woldia, Ethiopia
}

Background: Family planning helps to reduce poverty, increase gender equity, prevent the spread of sexually transmitted infections, and reduce maternal, infant, and childhood mortality. Hence, this study aimed to examine the association between exposure to mass media family planning messages and the utilization of modern contraceptives among urban and rural youth women in Ethiopia.

Methods: A comparative cross-sectional study using the 2016 Ethiopia Demographic and Health Survey (EDHS) data set was applied. The data were analyzed with SPSS version 20. Multivariate logistic regression analysis was performed to assess the association between exposure to mass media family planning messages and the utilization of modern contraceptives by controlling confounders. An adjusted odds ratio with a 95\% confidence interval was considered to declare a statistically significant association.

Results: The total sample was comprised of 6401 women (4061 from rural and 2340 from the urban area). There was no association between women exposed to mass media family planning messages and the utilization of modern contraceptives in rural areas. Surprisingly, this study showed that women exposed to mass media family planning messages in an urban area were less likely to use modern contraception by 62\% (AOR: 0.38 ; 95\% CI: $0.21,0.68$ ). Conclusion: The present study revealed that there was no significant association between women exposed to mass media family planning messages and utilization of modern contraceptives in rural areas. But, women exposed to mass media family planning messages in urban areas were less likely to use modern contraception. The study showed the role of inequalities in modern contraceptive utilization as shaped by structural and intermediary factors including religion, location, household wealth, education, and the number of children. This implies that the use of modern contraceptive use may be more impactful if cultural, geographical, and socioeconomic barriers are addressed.

Keywords: family planning message, youth women, modern contraceptive, Ethiopia

\section{Background}

The highest fertility rate in the world is found in sub-Saharan Africa, and a decline in birth rates has decelerated even more over the past decade with severe implications for the realization of health and development goals in Africa., ${ }^{1,2}$

Ethiopia has projected to decrease the total fertility rate (TFR) from 4.6 in 2012 to 1.8 in $2050 .^{3}$ Notwithstanding, the population is projected to reach 133.5 million 
in 2032 and 171.8 million in $2050 .{ }^{3}$ Therefore, to benefit from a demographic dividend, the country must first achieve a demographic transition through accelerating access to reproductive health and family planning services. $^{4,5}$

Even though Ethiopia achieved most of the healthrelated millennium development goals (MDGs) including a $67 \%$ reduction in under-five mortality, and a $71 \%$ decline in maternal mortality ratio, achieving the health-related sustainable development Goal (SDGs) requires the country to implement strategies, which specifically target more marginal populations and geographic areas. ${ }^{6}$

In response to this, the Ethiopia Ministry of Health $(\mathrm{MOH})$ has made the momentous step up in improving access to and quality of family planning (FP) throughout the country by enhancing mass media communication through the development of a costed implementation plan (CIP) for family planning as indispensable for aligning with global priorities as expressed in the SDG 5 which aims to achieve universal access to sexual and reproductive health-care services, including family planning. ${ }^{7,8}$

Undeniably, family planning helps to reduce poverty, increase gender equity, prevent the spread of HIV, and lower infant deaths. ${ }^{9}$ Multicountry studies have shown that accessing family planning can reduce maternal deaths by as much as $40 \%$, infant mortality by $10 \%$, and childhood mortality by $21 \%{ }^{10,11}$

Despite the advantages of accessing family planning, the contraceptives utilization rate for modern contraceptive use by currently married Ethiopian women is $35 \%{ }^{12}$ In the same vein, the unmet need for family planning for currently married women is $25 \%$ and $11 \%$ in rural and urban areas, respectively. ${ }^{12}$

Evidence showed that the provision of targeted, easily accessible, and accurate information about family planning through multiple channels increased the use of modern contraceptives, and influence social norms on its utilization. ${ }^{13-15}$

Studies have also shown that information through health care providers or the media can influence people positively in adopting family planning methods and encourage discussion about contraception between partners. ${ }^{16-18}$ A study conducted in Post-Soviet Central Asia illustrated that viewing family planning messages on television (TV) improves the chances of using modern contraception for a woman who saw the messages by about $8-11 \%{ }^{19}$ Another study conducted in Kenya showed that the proportion of women using a contraceptive method rises to
$25 \%$ among those who have heard radio messages, to $40 \%$ among those exposed to both radio and print messages and $50 \%$ among those exposed to radio, print, and television messages compared to $15 \%$ among women who say they have neither seen nor heard media messages. ${ }^{20}$

Scholars have also argued that the relationship between information and family planning utilization not always a linear relationship. ${ }^{19,21}$ This underscores the call for analyzing the effect of access to family planning information on the utilization of modern contraceptives by different populations and subgroups to guide audience segmentation for tailored family planning behavior change interventions. ${ }^{15}$

Observed evidence, which has been documented in copious studies, is chiefly promising regarding the effects of mass media campaigns in promoting family planning and individual contraceptive choices. ${ }^{22-24}$ There are at least dual reasons why exposure to mass media can help to promote the use of contraceptives. First, effective communication plays an important role in facilitating social interaction and development in general. In the context of developing countries, in particular, mass media plays an instrumental role in enhancing health communication by bridging the language gap in policy information dissemination to promote different health behaviours, ${ }^{25-27}$ including contraceptive behaviors. ${ }^{28}$

As health policies are often written with technical terms at the governmental level, mass media need to decode policy content to non-technical and understandable languages, which can effectively inform public perceptions about health issues. Second, in Ethiopia, health policies are typically written in English and at times in Amharic, Ethiopian's official language. Given the diverse linguistic nature of Ethiopia, coupled with the relatively low educational attainment, the mass media plays a crucial role in translating policy content into the various local languages for the wider audience.

Unfortunately, research assessing the impact of mass media family planning messages on the use of modern family planning methods in Ethiopia has lagged. Therefore, the current study endeavors to bridge this dearth by examining the association between family planning messages through mass media and the utilization of modern contraceptive methods among youth women in rural and urban areas of Ethiopia.

\section{Methods}

\section{Data Source}

The current comparative cross-sectional study analyzed using the 2016 Ethiopia Demographic and Health Survey (EDHS) data set. A detailed description of the study design and 
methodology of the survey was found elsewhere. ${ }^{12}$ A twostage stratified cluster sampling was used. Since Ethiopia has nine regional states and two city administrations, stratification was done by separating each structural division into urban and rural areas, except Addis Ababa (entirely urban). Therefore, a total of 23 sampling strata have been created. Then, each stratum was again further divided into enumeration areas (EAs) or clusters prepared by the 2007 Population and Housing Census as a sampling frame. In the first stage, a total of 645 EAs were selected. Of which, 202 were from urban areas. In the second stage, a fixed number of 28 households per cluster were selected randomly from the household listing. A total of 15,683 women (15-49 years) were interviewed, making up response rates of $95 \%$. The analytic sample for this study was 6401 women (4061 from the rural area and 2340 from the urban area).

\section{Selection Criteria}

The sample utilized in this study included (i) women who were the age group between 15 and 24 years residing in rural areas $(n=4061)$; and (ii) women who were the age group between 15 and 24 years residing in the urban area $(\mathrm{n}=2340)$ (Figure 1).

\section{Study Variables}

The outcome of this study was the utilization of modern contraception (pill, intrauterine device, injection, diaphragm, condom, sterilization, or implant). In this variable, we coded as 'yes' if respondents were utilized any of the modern contraception otherwise "not".
The main exposure variable in this study was family planning messages through different media (radio, television, newspaper/magazines, and mobile phones). The EDHS asks women whether they have been exposed to family planning messages on radio, television or print media (eg, magazines and newspapers), and through text messages in the last few months. Given that these four variables were highly correlated, we decided to create a variable called 'mass media exposure to family planning messages'. In this variable, we coded as "yes" if respondents were exposed to family planning messages on at least one of the four media outlets $(0$, no; 1 , yes). This categorization conforms with the coordination in the dissemination of media messages on central issues such as health, where television, radio, newspaper, and mobile phone media sources concurrently promote public health programs such that an individual who has access to any one of these media sources would be able to obtain the same information on a given public health issue.

To further account for possible confounding factors, we included age, religion, marital status, educational status of women, wealth index, and the number of children as independent variables. The wealth index was categorized into five categories according to the 2016 EDHS as the poorest, poorer, middle, richer and richest.

\section{Data Processing and Analysis}

The data were analyzed using Statistical Package for Social Science (SPSS) version 20. All statistical procedures incorporated complex sampling design analysis applied in the 2016 EDHS. Frequencies and weighted percentage of study

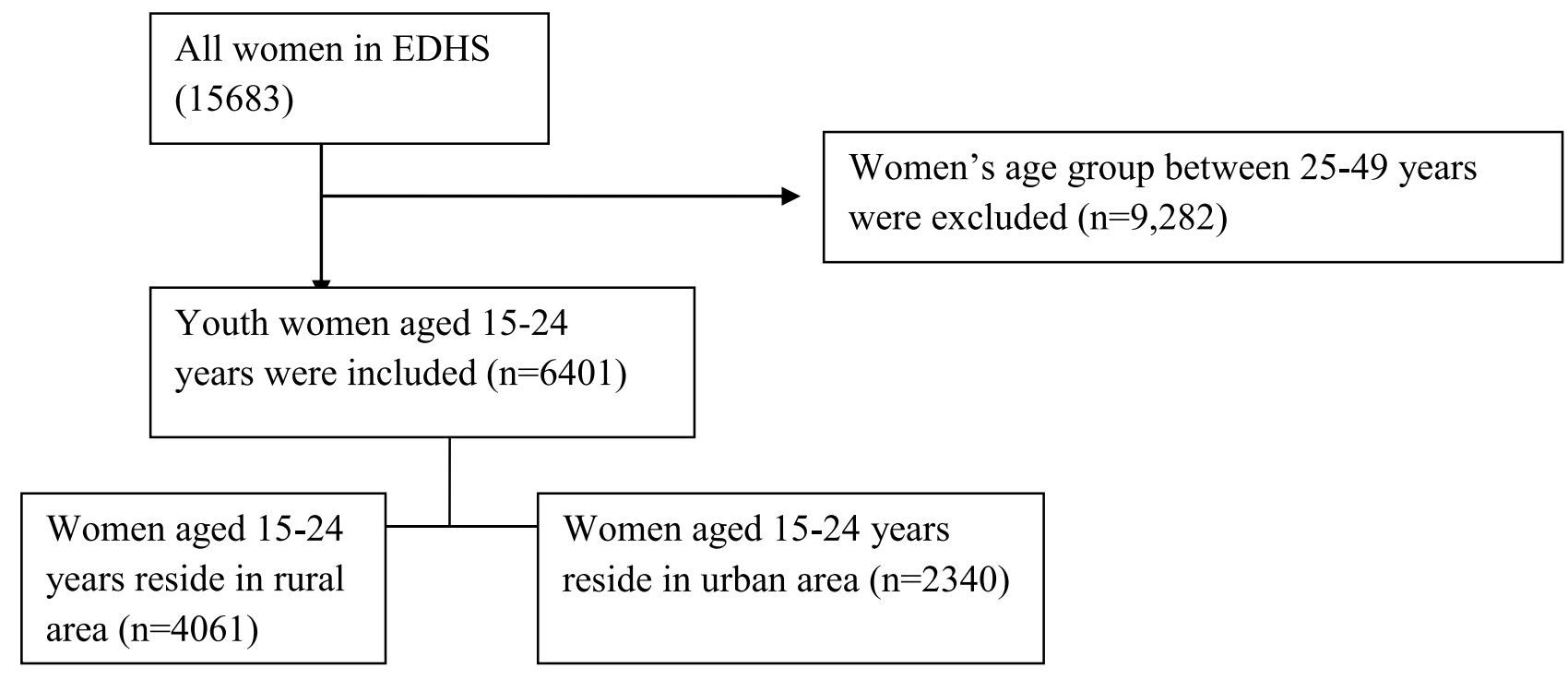

Figure I Flow chart showing how the weighted sample used in the study was derived. 
variables were calculated. Rao-Scott chi-square test was used to examine the relationship between modern contraceptive use and each of the independent variables separately for urban and rural residents. Multivariate logistic regression analysis was performed to assess the association between exposure to mass media family planning messages and modern contraceptive use by controlling confounders independently for urban and rural residents. All independent variables were entered into a multivariate logistic regression analysis model irrespective of the p-values in the statistical significance in the bivariate analysis. Adjusted odds ratios (AOR) were used to declare statistically significant association.

\section{Ethics Approval and Consent to Participate}

Ethical clearance for the study is not required since it is a secondary data analysis from the 2016 EDHS database. The researchers have received the survey data from USAID-DHS program and then the researchers of this study have maintained the confidentiality of the data. The consent was obtained from the study participants before study commencement.

\section{Results}

\section{Study Participant's Profiles About Modern Contraceptive Use}

Samples of 6941 women were included and analyzed. From the total sampled women, 4601 and 2340 of women were rural and urban residents, respectively. About, $72.4 \%$ of respondents aged 20-24 years from rural respondents were utilized modern contraceptives, compared with $79.4 \%$ of urban respondents. Similarly, $54.2 \%$ of the orthodox religious follower from rural respondents was used modern contraceptives at the time of the survey, compared with $72.8 \%$ of urban respondents (Tables 1 and 2). About, $88.9 \%$ of married women from rural area utilized modern contraceptives, compared with $81.2 \%$ of urban respondents. About, $60.7 \%, 13.6 \%$, and $1.5 \%$ of women attended primary, secondary and higher education in a rural area, respectively, did not utilize modern contraceptives (Table 1). Likewise in urban respondents, $35.6 \%, 39.2 \%$, and $20.6 \%$ of women attended primary, secondary and higher education, respectively, did not utilize modern contraceptives. The proportion of women utilized modern contraceptives in the rural area from the poorer, middle, and richer households were $32 \%$, $23.2 \%$, and $17.4 \%$, respectively. Similarly, the proportion of women utilized modern contraceptives in urban area from the poorer, middle, and richer households were $30.1 \%, 28.1 \%$, and $17.4 \%$, respectively (Table 2). Moreover, $25.5 \%$ of women who reside in a rural area utilized modern contraceptives had exposure to mass media family planning messages (Figure 2). About, 62.9\% of urban respondents utilized modern contraceptives had exposure to mass media family planning messages (Figure 3).

\section{Association Between Exposures to Mass Media Family Planning Messages and Modern Contraceptive Use}

All the variables were entered into multivariate logistic regression analysis. After adjusted for potential confounders; there is no association between women exposed to mass media family planning messages and the utilization of modern contraceptives in the rural area. However, women exposed to mass media family planning messages in the urban area were less likely to use modern contraception by 62\% (AOR: $0.38 ; 95 \%$ CI: $0.21,0.68$ ). In addition to the main exposure variable in this study, marital status, religion, educational status, wealth index, region, and the number of children were associated with modern contraceptive use.

Women currently married and separated or divorced were more likely to use modern contraceptives in both urban and rural areas of Ethiopia compared to nevermarried women.

The odds of modern contraceptive use were lower by 58\% (AOR: 0.42; 95\% CI: 0.26, 0.67) among Muslim religion followers in rural residents compared to Orthodox religion followers. Being Muslim and Protestant religion follower in urban area were less likely to use modern contraception by $62 \%$ (AOR: $0.38 ; 95 \% \mathrm{CI}$ : $0.16,0.89$ ) and 63\% (AOR: 0.37; 95\% CI: 0.15, 0.91), respectively (Table 3 ).

In the urban area, the likelihood of modern contraceptive use was 6.38 (AOR:6.38; 95\% CI: 1.18, 34.4), 5.55 (AOR:5.55; 95\% CI: 1.30, 23.7), and 7.67 (AOR: 7.67; 95\% CI: 1.90, 30.9) times higher among women attended primary, secondary, and higher education, respectively, compared to not educated one. But, in a rural area, women who attended higher education were 5.55 (AOR: 5.55; 95\% CI: $1.73,17.7)$ times higher to use modern contraception.

In the rural area, women who had wealth index class of middle, richer and richest were 2.05 (AOR: 2.05; 95\% CI: 1.23, 3.41), 2.77 (AOR: 2.77; 95\% CI: 1.73, 4.44), and 
Table I Profile of Respondents About the Utilization of Modern Contraceptives Among Rural Youths Women in Ethiopia ( $n=406 \mathrm{I}$ )

\begin{tabular}{|c|c|c|c|c|}
\hline \multirow[t]{3}{*}{ Variables } & \multirow[t]{3}{*}{ Category } & \multicolumn{2}{|l|}{ Rural } & \multirow{2}{*}{$\begin{array}{l}\text { Chi-Square } \\
\text { P value }\end{array}$} \\
\hline & & Not Used Modern Contraceptives & Used Modern Contraceptives & \\
\hline & & n (wt. \%) & n (wt. \%) & \\
\hline Age & $\begin{array}{l}15-19 \\
20-24\end{array}$ & $\begin{array}{l}2109(60.2) \\
1411(39.8)\end{array}$ & $\begin{array}{l}143(27.6) \\
398(72.4)\end{array}$ & $<0.001$ \\
\hline Religion & $\begin{array}{l}\text { Orthodox } \\
\text { Catholic } \\
\text { Protestant } \\
\text { Muslim } \\
\text { Other }\end{array}$ & $\begin{array}{l}1039(34.7) \\
24(1.0) \\
707(25.3) \\
1712(37.3) \\
38(1.9)\end{array}$ & $\begin{array}{l}287(54.2) \\
5(1.4) \\
127(24.4) \\
119(19.3) \\
3(0.6)\end{array}$ & $<0.001$ \\
\hline Marital status & $\begin{array}{l}\text { Single } \\
\text { Married } \\
\text { Separated/divorced }\end{array}$ & $\begin{array}{l}1922(60.5) \\
1409(33.6) \\
189(5.9)\end{array}$ & $\begin{array}{l}23(3.7) \\
481(88.9) \\
37(7.4)\end{array}$ & $<0.001$ \\
\hline Women education & $\begin{array}{l}\text { No education } \\
\text { Primary } \\
\text { Secondary } \\
\text { Higher }\end{array}$ & $\begin{array}{l}1108(24.2) \\
1852(60.7) \\
494(13.6) \\
66(1.5)\end{array}$ & $\begin{array}{l}138(29.0) \\
300(55.3) \\
81(12.4) \\
22(3.2)\end{array}$ & 0.052 \\
\hline Wealth index & $\begin{array}{l}\text { Poorest } \\
\text { Poorer } \\
\text { Middle } \\
\text { Richer } \\
\text { Richest }\end{array}$ & $\begin{array}{l}1130(22.7) \\
583(24.3) \\
514(23.7) \\
456(22) \\
182(7.3)\end{array}$ & $\begin{array}{l}61(24.4) \\
54(32.0) \\
42(23.2) \\
36(17.4) \\
10(3.0)\end{array}$ & 0.069 \\
\hline Region & $\begin{array}{l}\text { Tigray } \\
\text { Afar } \\
\text { Amhara } \\
\text { Oromia } \\
\text { Somali } \\
\text { Benishangul Gumuz } \\
\text { SNNPR } \\
\text { Gambela } \\
\text { Harari } \\
\text { Dire Dawa }\end{array}$ & $\begin{array}{l}449(7.5) \\
407(1.0) \\
402(21.2) \\
559(41.8) \\
432(3.8) \\
301(1.1) \\
521(23.0) \\
211(0.2) \\
146(0.2) \\
92(0.2)\end{array}$ & $\begin{array}{l}95(9.9) \\
7(0.1) \\
140(38.7) \\
77(29.2) \\
1(0.0) \\
67(1.3) \\
86(20.3) \\
41(0.3) \\
16(0.1) \\
11(0.1)\end{array}$ & $<0.001$ \\
\hline Number of children & $\begin{array}{l}0 \\
1-2 \\
3+\end{array}$ & $\begin{array}{l}2410(71.8) \\
922(23.5) \\
188(4.7)\end{array}$ & $\begin{array}{l}151(27.5) \\
358(66.5) \\
32(6.1)\end{array}$ & $<0.001$ \\
\hline Mass media exposure & $\begin{array}{l}\text { No } \\
\text { Yes }\end{array}$ & $\begin{array}{l}2816(77.4) \\
704(22.6)\end{array}$ & $\begin{array}{l}38 \mid(74.5) \\
160(25.5)\end{array}$ & 0.22 \\
\hline
\end{tabular}

2.54 (AOR: 2.54 ; $95 \%$ CI: $1.25,5.18$ ) times more likely to use modern contraceptive, respectively, compared to women who had poorest wealth index. As well, the odds of modern contraceptive use were 15.8 (AOR: $15.8 ; 95 \%$ CI: $1.73,145$ ), and 40.8 (AOR: 40.8 ; 95\% CI: 3.65, 456.2) times higher among women who had wealth index class of poorer, and richer, respectively.

Regarding region in the country, the odds of modern contraceptive use was 3.05 (AOR: 3.05 ; 95\% CI: 1.76 ,
5.25) times higher among women who reside in rural Amhara region compared to Oromiya. Women lived in Somali region were less likely to use modern contraception by $97 \%$ (AOR: $0.03 ; 95 \%$ CI: $0.003,0.18$ ) in rural and by $99 \%$ (AOR: $0.01 ; 95 \%$ CI: $0.003,0.45$ ) in urban residents.

Moreover, women who had 1-2 children were 1.92 (AOR: 1.92; 95\% CI: 1.37, 2.67) and 2.54 (AOR: 2.54; 95\% CI: $1.14,5.66)$ times more likely to use modern 
Table 2 Profile of Respondents in Relation to Utilization of Modern Contraceptives Among Urban Youths Women in Ethiopia $(n=2340)$

\begin{tabular}{|c|c|c|c|c|}
\hline \multirow[t]{3}{*}{ Variables } & \multirow[t]{3}{*}{ Category } & \multicolumn{2}{|l|}{ Urban } & \multirow{3}{*}{$\begin{array}{l}\text { Chi-Square } \\
\text { P value }\end{array}$} \\
\hline & & \multirow{2}{*}{$\begin{array}{l}\text { Not Used Modern Contraceptives } \\
\text { n (wt. \%) }\end{array}$} & \multirow{2}{*}{$\begin{array}{l}\text { Used Modern Contraceptive } \\
\text { n (wt. \%) }\end{array}$} & \\
\hline & & & & \\
\hline Age & $\begin{array}{l}15-19 \\
20-24\end{array}$ & $\begin{array}{l}1182(61.4) \\
803(38.6)\end{array}$ & $\begin{array}{l}64(20.6) \\
291(79.4)\end{array}$ & $<0.001$ \\
\hline Religion & $\begin{array}{l}\text { Orthodox } \\
\text { Catholic } \\
\text { Protestant } \\
\text { Muslim } \\
\text { Other }\end{array}$ & $\begin{array}{l}1061(57.1) \\
8(0.4) \\
255(22.6) \\
658(19.7) \\
3(0.1)\end{array}$ & $\begin{array}{l}226(72.8) \\
8(0.4) \\
46(10.5) \\
80(12.1) \\
3(1.2)\end{array}$ & 0.026 \\
\hline Marital status & $\begin{array}{l}\text { Single } \\
\text { Married } \\
\text { Separated/divorced }\end{array}$ & $\begin{array}{l}1618(85.5) \\
284(10.5) \\
83(4.0)\end{array}$ & $\begin{array}{l}59(14.2) \\
273(81.2) \\
23(4.6)\end{array}$ & $<0.001$ \\
\hline Women education & $\begin{array}{l}\text { No education } \\
\text { Primary } \\
\text { Secondary } \\
\text { Higher }\end{array}$ & $\begin{array}{l}146(4.6) \\
790(35.6) \\
681(39.2) \\
368(20.6)\end{array}$ & $\begin{array}{l}16(2.5) \\
162(40.7) \\
105(32.2) \\
72(24.5)\end{array}$ & 0.242 \\
\hline Wealth index & $\begin{array}{l}\text { Poorest } \\
\text { Poorer } \\
\text { Middle } \\
\text { Richer } \\
\text { Richest }\end{array}$ & $\begin{array}{l}197(12.5) \\
286(17.1) \\
409(21.7) \\
426(22.7) \\
667(26.0)\end{array}$ & $\begin{array}{l}29(14.5) \\
94(30.1) \\
129(28.1) \\
58(17.4) \\
45(10.0)\end{array}$ & 0.069 \\
\hline Region & $\begin{array}{l}\text { Tigray } \\
\text { Afar } \\
\text { Amhara } \\
\text { Oromia } \\
\text { Somali } \\
\text { Benishangul- Gumuz } \\
\text { SNNPR } \\
\text { Gambela } \\
\text { Harari } \\
\text { Addis Ababa } \\
\text { Dire Dawa }\end{array}$ & $\begin{array}{l}159(8.5) \\
55(0.8) \\
70(16.1) \\
90(25.4) \\
136(2.9) \\
60(0.9) \\
86(13.4) \\
122(0.6) \\
179(0.6) \\
706(28.9) \\
92(0.2)\end{array}$ & $\begin{array}{l}37(10.0) \\
31(2.2) \\
20(26.2) \\
15(23.1) \\
4(0.4) \\
19(1.6) \\
20(12.9) \\
39(1.0) \\
38(0.7) \\
88(20.0) \\
11(0.1)\end{array}$ & 0.031 \\
\hline Number of children & $\begin{array}{l}0 \\
1-2 \\
3+\end{array}$ & $\begin{array}{l}1807(94.2) \\
159(5.6) \\
19(0.3)\end{array}$ & $\begin{array}{l}155(49.8) \\
195(49.6) \\
5(0.6)\end{array}$ & $<0.001$ \\
\hline Mass media exposure & $\begin{array}{l}\text { No } \\
\text { Yes }\end{array}$ & $\begin{array}{l}598(26.3) \\
1387(73.7)\end{array}$ & $\begin{array}{l}108(37.1) \\
247(62.9)\end{array}$ & 0.03 \\
\hline
\end{tabular}

contraceptive in rural and urban residents, respectively, compared to women who did not have children (Table 3).

\section{Discussion}

The study found that there was no association between women exposed to family planning messages with the utilization of modern contraceptives in a rural area. This finding is contrasted with studies conducted in post-soviet Central Asia, ${ }^{19}$ Bangladesh, $^{24}{ }^{2}$ Nigeria, ${ }^{22}$ and Kenya, ${ }^{20}$ which showed that information about family planning messages through mass media positively affects modern contraceptive use. 


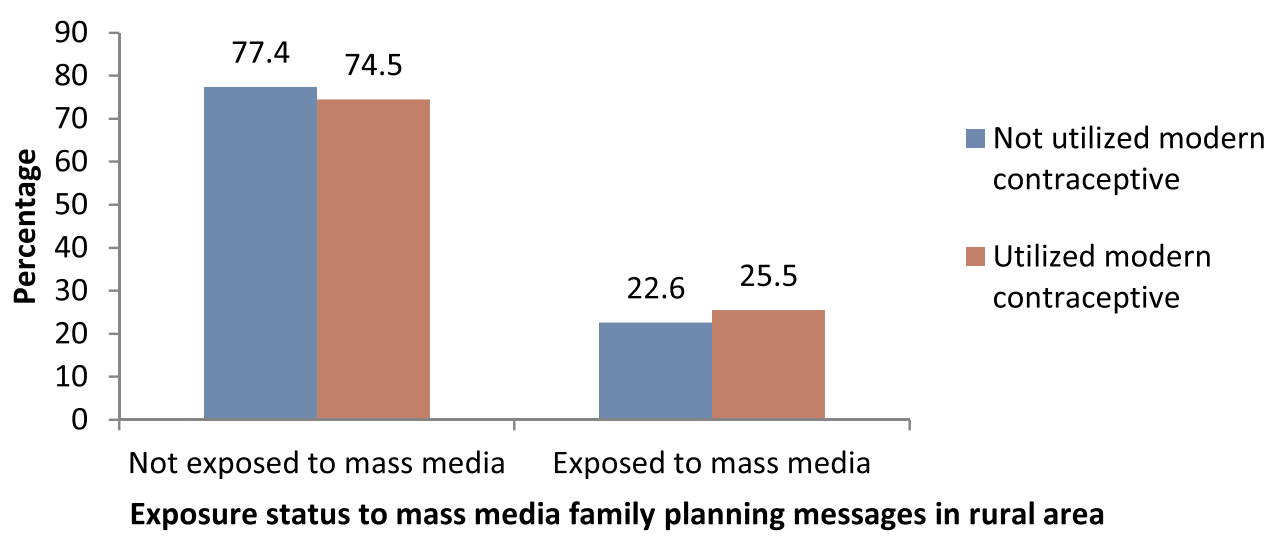

Figure 2 The magnitude of modern contraceptive use in relation to mass media family planning messages in rural area $(n=406 \mathrm{I})$.

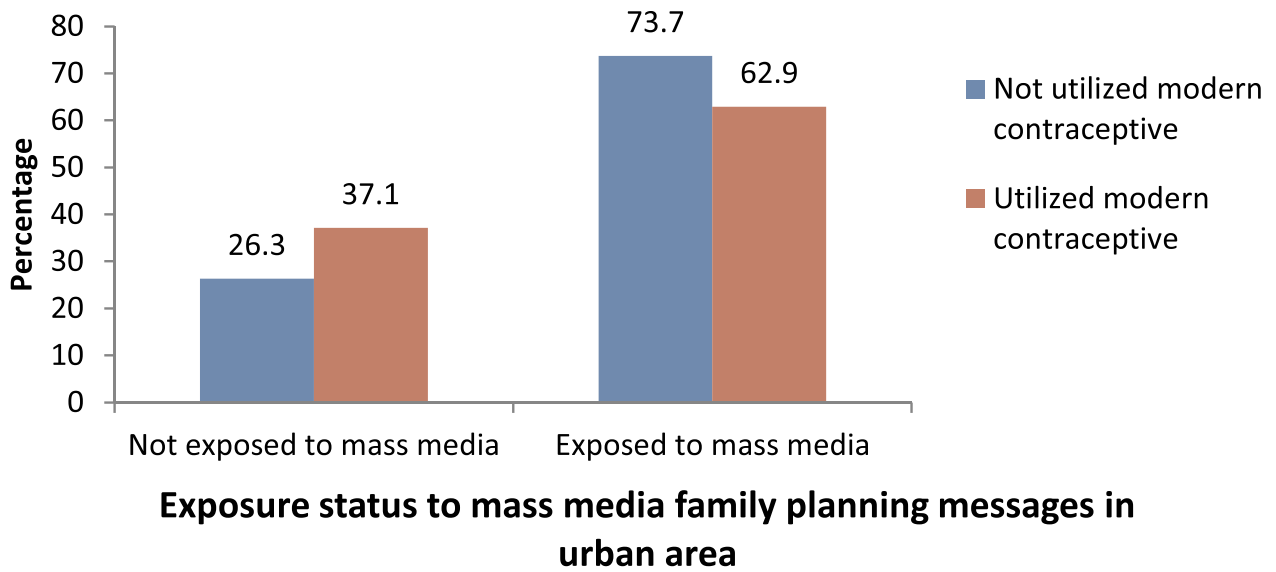

Figure 3 The magnitude of modern contraceptive use in relation to mass media family planning messages in urban area $(n=2340)$.

On contrary, women who heard about family planning messages through mass media in urban areas were more likely to use modern contraception. This finding is contrasted with studies conducted in Kenya, ${ }^{20}$ Tanzania, ${ }^{17}$ and Nigeria. ${ }^{13}$ The difference may be explained by socioeconomic differences between countries, which matters the quality and quantity of information delivered through different media and sample size differences between studies.

In addition to the main exposure variable marital status, religion, educational status, wealth index, region, and the number of children was associated with modern contraceptive use.

In this study, women currently married and separated/ divorced were more likely to use modern contraceptives in both urban and rural areas of Ethiopia compared to nevermarried women. This may be explained as marriage broadens the social capital base of women, which improves the potential for accessing media resources through social networks and joint decision making from a husband.
The odds of modern contraceptive use were lower among Muslim religious followers in both rural and urban residents compared to Orthodox religious followers. As well, being protestant religious followers in the urban area were less likely to use lowers the odds of modern contraception. This finding is similar to studies conducted in SubSaharan Africa, ${ }^{29}$ Nigeria, ${ }^{30}$ Zambia, ${ }^{31}$ and Ethiopia. ${ }^{32}$ This may be due to religious factors have the potential to influence the acceptance and use of contraception by couples from different religious backgrounds in very distinct ways. $^{32}$

In the urban area, the odds of modern contraceptive use were increased as the level of education increased compared to non-educated ones. But, in a rural area, merely women who attended higher education were more likely to use modern contraceptives. This finding is supported by studies conducted in Ethiopia, ${ }^{34}$ and Nigeria. ${ }^{35,36}$ This may be explained by the notion that women with better educational levels have increased knowledge and a positive attitude about 
Table 3 Bivariate and Multivariate Analyses to Assess the Association Between Exposure to Mass Media Family Planning Messages and Modern Contraceptive Uses Among Youth Women in Ethiopia

\begin{tabular}{|c|c|c|c|c|c|}
\hline \multirow[t]{2}{*}{ Variables } & \multirow[t]{2}{*}{ Category } & \multicolumn{2}{|l|}{ Rural } & \multicolumn{2}{|l|}{ Urban } \\
\hline & & $\operatorname{COR}(95 \% \mathrm{Cl})$ & AOR(95\% Cl) & $\operatorname{COR}(95 \% \mathrm{CI})$ & $\operatorname{AOR}(95 \% \mathrm{Cl})$ \\
\hline Age & $\begin{array}{l}15-19 \\
20-24\end{array}$ & $\begin{array}{l}1 \\
3.98(3.07-5.15)\end{array}$ & $\begin{array}{l}\text { I } \\
0.91(0.65,1.25)\end{array}$ & $\begin{array}{l}1 \\
6.13(3.38-11.1)\end{array}$ & $\begin{array}{l}\text { I } \\
\text { I.69(0.95,3.0I) }\end{array}$ \\
\hline Religion & $\begin{array}{l}\text { Orthodox } \\
\text { Catholic } \\
\text { Protestant } \\
\text { Muslim } \\
\text { Other }\end{array}$ & $\begin{array}{l}\text { I } \\
0.91(0.3 I-2.62) \\
0.62(0.45-0.83) \\
0.33(0.23-0.47) \\
0.23(0.04-1.37)\end{array}$ & $\begin{array}{l}\text { I } \\
\text { I.5I }(0.63,3.68) \\
I .21 \mathrm{I}(0.692,2.12) \\
0.42(0.26,0.68)^{*} \\
0.32(0.06,1.73)\end{array}$ & $\begin{array}{l}\text { I } \\
0.8 I(0.2 I-2.72) \\
0.48(0.25-0.90) \\
0.48(0.27-0.83) \\
6.72(0.61-7.46)\end{array}$ & $\begin{array}{l}\text { I } \\
\text { I.2I }(0.63,4.53) \\
0.38(0.16,0.89)^{*} \\
0.37(0.15,0.91)^{*} \\
3.64(0.97,13.5)\end{array}$ \\
\hline Marital status & $\begin{array}{l}\text { Single } \\
\text { Married } \\
\text { Separated/divorced }\end{array}$ & $\begin{array}{l}\text { I } \\
42.8(23.9-7.67) \\
20.3(10.4-39.9)\end{array}$ & $\begin{array}{l}\text { I } \\
58.1(31.0,108)^{*} \\
18.7(8.7,40.2)^{*}\end{array}$ & $\begin{array}{l}\text { I } \\
46.5(27.7-77.9) \\
6.89(2.37-19.9)\end{array}$ & $\begin{array}{l}\text { I } \\
39.7(20.1,78.8)^{*} \\
4.7(1.84,12.2)^{*}\end{array}$ \\
\hline Women education & $\begin{array}{l}\text { No education } \\
\text { Primary } \\
\text { Secondary } \\
\text { Higher }\end{array}$ & $\begin{array}{l}\text { I } \\
0.76(0.55-1.04) \\
0.76(0.5 I-I .15) \\
I .73(0.83-3.64)\end{array}$ & $\begin{array}{l}\text { I } \\
\text { I.I7(0.82,I.67) } \\
\text { I.45(0.87,2.42) } \\
5.55(I .73,17.7)^{*}\end{array}$ & $\begin{array}{l}\text { I } \\
2.08(0.59-7.26) \\
\text { I.49(0.44-5.II) } \\
2.18(0.76-6.17)\end{array}$ & $\begin{array}{l}\text { I } \\
6.35(1.18,34.4)^{*} \\
5.55(1.30,23.7)^{*} \\
7.67(1.90,30.9)^{*}\end{array}$ \\
\hline Wealth index & $\begin{array}{l}\text { Poorest } \\
\text { Poorer } \\
\text { Middle } \\
\text { Richer } \\
\text { Richest }\end{array}$ & $\begin{array}{l}\text { I } \\
1.68(1.11-2.56) \\
1.72(1.14-2.59) \\
1.69(1.16-2.46) \\
1.90(1.12-3.22)\end{array}$ & $\begin{array}{l}\text { I } \\
\text { I.63(0.95,2.78) } \\
2.04(1.23,3.40)^{*} \\
2.77(1.73,4.43)^{*} \\
2.69(1.33,5.42)^{*}\end{array}$ & $\begin{array}{l}\text { I } \\
\text { I3.I(0.78-2|.8) } \\
0.39(0.03-6.22) \\
27.3(2.94-252) \\
5.02(0.74-33.7)\end{array}$ & $\begin{array}{l}\text { I } \\
\text { I5.5(I.78, I35)* } \\
0.58(0.05,6.62) \\
40.7(3.99,4 \mid 6)^{*} \\
3.75(0.85,16.5)\end{array}$ \\
\hline Region & $\begin{array}{l}\text { Tigray } \\
\text { Afar } \\
\text { Amhara } \\
\text { Oromia } \\
\text { Somali } \\
\text { Benishangul-Gumuz } \\
\text { SNNPR } \\
\text { Gambela } \\
\text { Harari } \\
\text { Dire Dawa } \\
\text { Addis Ababa }\end{array}$ & $\begin{array}{l}1.87(1.22-2.87) \\
0.15(0.07-0.36) \\
2.61(1.80-3.79) \\
I \\
0.01(0.002-0.09) \\
1.66(1.04-2.66) \\
1.26(0.84-1.92) \\
2.16(1.21-3.85) \\
0.78(0.43-1.42) \\
1.01(0.35-2.88) \\
-\end{array}$ & $\begin{array}{l}1.53(0.90,2.58) \\
0.27(0.11,0.69) \\
3.05(1.76,5.25)^{*} \\
I \\
0.03(0.003,0.18)^{*} \\
1.47(0.86,2.52) \\
1.16(0.67,2.02) \\
1.22(0.62,2.38) \\
0.66(0.34,1.28) \\
1.62(0.56,4.64) \\
-\end{array}$ & $\begin{array}{l}1.29(0.64-2.63) \\
3.02(1.29-7.04) \\
1.79(0.82-3.94) \\
1 \\
0.17(0.04-0.64) \\
2.11(0.62-7.13) \\
1.06(0.45-2.49) \\
1.97(0.94-4.15) \\
1.30(0.68-2.45) \\
0.93(0.47-1.82) \\
0.76(0.41-1.43)\end{array}$ & $\begin{array}{l}0.61(0.18,1.98) \\
1.74(0.39,7.80) \\
166(0.51,5.45) \\
1 \\
0.01(0.003,0.45)^{*} \\
0.75(0.17,3.21) \\
0.39(0.10,1.57) \\
0.65(0.11,3.81) \\
0.72(0.22,2.35) \\
0.68(0.31,2.99) \\
0.96(0.31,2.99)\end{array}$ \\
\hline Number of children & $\begin{array}{l}0 \\
\mathrm{I}-2 \\
3+\end{array}$ & $\begin{array}{l}\text { I } \\
7.4 I(5.50-9.93) \\
3.38(1.86-6.14)\end{array}$ & $\begin{array}{l}\text { I } \\
\text { I.92(I.37,2.67)* } \\
\text { I.19(0.6I, 2.34) }\end{array}$ & $\begin{array}{l}\text { I } \\
16.8(9.20-30.9) \\
4.18(1.21-14.4)\end{array}$ & $\begin{array}{l}\text { I } \\
2.54(1.14,5.66)^{*} \\
5.57(0.31,10.1)\end{array}$ \\
\hline Mass media & $\begin{array}{l}\text { No } \\
\text { Yes }\end{array}$ & $\begin{array}{l}\mathrm{I} \\
1.17(0.9 \mid-1.53)\end{array}$ & $\begin{array}{l}\text { I } \\
1.20(0.85-1.70)\end{array}$ & $\begin{array}{l}\text { I } \\
0.61(0.38-0.95)\end{array}$ & $\begin{array}{l}\text { I } \\
0.38(0.21-0.68)^{*}\end{array}$ \\
\hline
\end{tabular}

Notes: *Statistically significant association by adjusted odds ratio with $95 \%$ confidence interval.

modern contraceptives by having better access to health care information, greater autonomy to make decisions, a greater ability to use quality health care services and increase women's understanding of reproductive health issues like child spacing. ${ }^{37-39}$

In a rural area, women in the middle, richer, and richest wealth quintiles were more likely to use modern contraceptives. Also, in the urban area, odds of modern contraceptive use were higher among women who had wealth index class of poorer, and richer compared to the poorest. This finding is in line with studies conducted in Mozambique, ${ }^{40}$ Ghana, ${ }^{41}$ Liberia, ${ }^{42}$ and Malawi. ${ }^{43}$ This might be due to the capacity to purchase modern contraceptives not necessarily relying on their partners. The wealth variable was an aggregate index of assets, with many having assets such as cell phones, radios, televisions, motorbikes, cars, or bicycles, all of which can 
contribute to other important factors such as access to information, transport, and educational level. ${ }^{44}$ Besides, the ability of women to access information on contraceptives on mass media platforms such as radio, newspapers, magazines and television may be challenging for those who are the poorest, like the acquisition, use and maintenance of gadgets such as radios and televisions require substantial financial investments.

Regarding region in the country, the odds of modern contraceptive use were higher among women who reside in the rural Amhara region. Women who lived in the Somali region were less likely to use modern contraceptive $97 \%$ in rural and by $99 \%$ in urban residents. This might be due to cultural as well as geographical information gap on modern contraceptive methods utilization across the region within the country; for instance, the percentage of women aged 15-49 who have heard of at least one modern method in Amhara and Somali region were $99.9 \%$ and $78.6 \%$, respectively. ${ }^{12}$

Moreover, women who had 1-2 children were more likely to use modern contraceptives in rural and urban residents compared to women who did not have children. This finding is supported by studies conducted in Afghanistan, ${ }^{45}$ and Ethiopia. ${ }^{46,47}$ This might be explained as when women reach their desired number of children, they used contraception for not becoming pregnant, rather than for birth spacing or reducing the number of their desired children.

\section{Weaknesses and Strengths of the Study}

Although findings in this study are useful for policy, there are some noteworthy limitations. For example, the reliability of self-reported surveys such as the EDHS may be questionable because of possible under-reporting. Further, the data were collected in a retrospective study design and our study may not be devoid of the shortcomings associated with this approach. To minimize recall bias, the main variable of interest "exposure to mass media family planning messages" was explicit in limiting exposure to the last few months. Notwithstanding these limitations, our study is one of the few that have contributed in the context of media exposure and family planning utilization, as no other studies done in the country using national representative data up to date.

\section{Conclusions}

The present study revealed that there is no association between women's exposure to mass media family planning messages and the utilization of modern contraceptives in the rural area. However, women exposed to mass media family planning messages in urban areas lagged from modern contraceptive use. Our findings also highlighted that the role of inequalities in modern contraceptive utilization as shaped by structural and intermediary factors including religion, location, household wealth, education, and the number of children. This implies that the use of modern contraceptive use may be more impactful if cultural, geographical, and socioeconomic barriers are addressed. For example, it may be helpful to provide culturally and religiously sensitive educational programs to inform women about the importance of family planning. Finally, the messages that were used should be a target for further qualitative and quantitative research to better understand why messaging is not having the intended effect.

\section{Abbreviations}

AOR, Adjusted Odds Ratio; CI, confidence interval; EDHS, Ethiopia Demographic and Health Survey; SNNPR, Southern Nations, Nationalities, and People's Region; SPSS, Statistical Package for Social Science.

\section{Data Sharing Statement}

For this analysis, we used the USAID-DHS program 2016 Ethiopian demographic and health survey data set. To request the same or different data for another purpose, a new research project request should be submitted to the DHS program here: https://dhsprogram.com/data/AccessInstructions.cfm. The DHS Program will normally review all data requests within $24-48$ hours (during working days) and provide notification if access has been granted, or additional project information is needed before access can be granted. After receiving permission, the researcher can log in and select the specific data in the format they prefer.

\section{Acknowledgments}

We are grateful to the USAID-DHS program for providing access to the 2016 Ethiopia Demographic and Health Survey.

\section{Author Contributions}

All authors made a significant contribution to the work reported, whether that is in the conception, study design, execution, acquisition of data, analysis, and interpretation, or in all these areas; took part in drafting, revising or critically reviewing the article; gave final approval of the 
version to be published; have agreed on the journal to which the article has been submitted; and agree to be accountable for all aspects of the work.

\section{Disclosure}

The authors confirm that this research is our original paper and that there is no conflict of interest in this work.

\section{References}

1. Cleland JG, Ndugwa RP, Zulu EM. Family planning in Sub-Saharan Africa: progress or stagnation? Bull World Health Organ. 2011;89:137-143. doi:10.2471/BLT.10.077925

2. Bongaarts J. Fertility transitions in developing countries: progress or stagnation? Stud Fam Plann. 2008;39:105-110.

3. Bekele A, Lakew Y. Projecting Ethiopian demographics from 2012-2050 using the spectrum suite of models. Ethiop Public Health Assoc. 2014.

4. Population Reference Bureau. Harnessing the demographic dividend; 2013. Available from: http://www.prb.org/Multimedia/Video/2013/ demographic-dividend-engage.aspx. Accessed August 27, 2020.

5. Bloom D, Canning D, Sevilla J. The Demographic Dividend: A New Perspective on the Economic Consequences of Population Change. Santa Monica, CA: RAND; and Population Reference Bureau; 2013.

6. Assefa Y, Damme WV, Williams OD, et al. Successes and challenges of the millennium development goals in Ethiopia: lessons for the sustainable development goals. BMJ Glob Health. 2017;2:e000318. doi:10.1136/bmjgh-2017-000318

7. Ministry of Health. Costed Implementation Plan for Family Planning in Ethiopia, 2015/16-2020. 2016

8. Dockalova B, Lau K, Barclay H, Marshall A Sustainable development goals and family planning 2020. The International Planned Parenthood Federation (IPPF); 2016. United Kingdom. Available from: https://www.ippf.org/sites/default/files/2016-11/SDG\%20and\% 20FP2020.pdf. Accessed August 27, 2020.

9. Singh S, Jacqueline ED, Ashford L. Adding it up: the need for and cost of maternal and newborn care- estimates for 2012. New York: Guttmacher Institute. Available from: http://www.guttmacher.org/ pubs/AIU-MNH-2012-estimates.pdf. Accessed August 27, 2020.

10. Cleland J, Conde-Agudelo A, Peterson H, Ross J, Tsui A. Contraception and health. Lancet. 2012;380:149-156. doi:10.1016/ S0140-6736(12)60609-6

11. Ahmed S, Li Q, Liu L, Tsui A. Maternal deaths averted by contraception use: an analysis of 172 countries. Lancet. 2012;380:111-125. doi:10.1016/S0140-6736(12)60478-4

12. ICF CSA (CSA) [Ethiopia]. Ethiopia Demographic and Health Survey 2016. Addis Ababa, Ethiopia: Rockville, Maryland; 2016.

13. Measurement, Learning and Evaluation Project Nigeria Team. Evaluation of the Nigerian urban reproductive health initiative (NURHI) program. Stud Fam Plann. 2017;48:253-268.

14. Isonguyo I, Adindu A. Adolescents and utilization of family planning service in rural community of Nigeria. Res Humanit Soc Sci. 2013;3:1.

15. Bongaarts J, Cleland J, Townsend JW, et al. Family Planning Programs for the 21st Century Rationale and Design. New York, NY: Population Council; 2012.

16. Jato NM, Simbakalia C, Tarasevich JM, et al. The impact of multi-media family planning promotion on the contraceptive behavior of women in Tanzania. Int Fam Plan Perspect. 1999;25:60-67. doi: $10.2307 / 2991943$

17. Kiragu K, Krenn S, Kusemiju B, et al. Promoting Family Planning Through Mass Media in Nigeria: Campaigns Using Public Service Announcements and a National Logo. Baltimore, MD: John Hopkins Centre for Communication Programs; 1996.
18. Kabagenyi A, Ndugga P, Wandera SO, et al. Modern contraceptive use among sexually active men in Uganda: does discussion with a health worker matter? BMC Public Health. 2014;14:286. doi:10.1186/1471-2458-14-286

19. Habibov N, Zainiddinov H. Effect of TV and radio family planning messages on the probability of modern contraception utilization in post-Soviet Central Asia. Int J Health Plann Manag. 2015;32(1):e17-38.

20. Westoff CF, Rodriguez G. The mass media and family planning in Kenya. Int Fam Plan Perspect. 1995;21(1):26. doi:10.2307/2133602

21. Omoera OS. Broadcast media in family planning matters in rural Nigeria: the Ebelle scenario. J Commun. 2010;1:77-85. doi:10.1080/ 0976691X.2010.11884773

22. Kincaid D. Social networks, ideation, and contraceptive behavior in Bangladesh: a longitudinal analysis. Soc Sci Med. 2000;50:215-231. doi:10.1016/S0277-9536(99)00276-2

23. Babalola S, Folda L, Babayaro H. The effects of a communication program on contraceptive ideation and use among young women in Northern Nigeria. Stud Fam Plann. 2008;39:211-220.

24. Guilkey K, Hutchinson L. Overcoming methodological challenges in evaluating health communication campaigns: evidence from rural Bangladesh. Stud Fam Plann. 2011;42:93-106.

25. Mosonsieyiri Kansanga M, Asumah Braimah J, Antabe R, Sano Y, Kyeremeh E, Luginaah I. Examining the association between exposure to mass media and health insurance enrolment in Ghana. Int J Health Plann Manag. 2018. doi:10.1002/hpm.2505,

26. Sano Y, Sedziafa AP, Amoyaw JA, et al. Exploring the linkage between exposure to mass media and HIV testing among married women and men in Ghana. AIDS Care. 2016;28(6):684-648. doi:10.1080/09540121.2015.1131970

27. Wakefield MA, Loken B, Hornik RC. Use of mass media campaigns to change health behaviour. Lancet. 2010;376(9748):1261-1271. doi:10.1016/S0140-6736(10)60809-4

28. David O, Bankole A. The impact of mass media family planning promotion on contraceptive behavior of women in Ghana. Popul Res Policy Rev. 1994;13:161-177. doi:10.1007/BF01080201

29. Farrell M, Masquelier A, Tissot E, Bertrand J. Islam, polygyny and modern contraceptive use in Francophone Sub-Saharan Africa. Afr Popul Stud. 2014;28(3):1389-1398.

30. Obasohan PE. Religion, ethnicity and contraceptive use among reproductive age women in Nigeria. Int J MCH AIDS. 2015;3(1):63-73.

31. Lasong J, Zhang Y, Gebremedhin SA, et al. Determinants of modern contraceptive use among married women of reproductive age: a cross- sectional study in rural Zambia. BMJ Open. 2020;10: e030980. doi:10.1136/bmjopen-2019-030980

32. Tiruneh FN, Chuang KY, Ntenda PAM, et al. Factors associated with contraceptive use and intention to use contraceptives among married women in Ethiopia. Women Health. 2016;56:1-22. doi:10.1080/ 03630242.2015.1074640

33. Srikanthan A, Reid RL. Religious and Cultural Influences on Contraception. J Obstet Gynaecol Can. 2008;30(2):129-137.

34. Alemayehu GA, Fekadu A, Yitayal M, et al. Prevalence and determinants of contraceptive utilization among married women at Dabat Health and Demographic Surveillance System site, northwest Ethiopia. BMC Womens Health. 2018;18(1):118. doi:10.1186/ s12905-018-0611-3

35. Solanke BL. Factors influencing contraceptive use and non-use among women of advanced reproductive age in Nigeria. $J$ Health Popul Nutr. 2017;36(1):1. doi:10.1186/s41043-016-0077-6

36. Ogboghodo EO, Adam VY, Wagbatsoma VA. Prevalence and determinants of contraceptive use among women of child bearing age in a rural community in Southern Nigeria Keywords. J Commun Med Primary Health Care. 2017;29(2):97-107.

37. Tunau K, Awosan KJ, Adamu H, et al. Comparative assessment of modern contraceptives' knowledge and utilization among women in urban and rural communities of Sokoto State, Nigeria. J Med Med Sci. 2016;7(1):614. 
38. Eko Jimmy E, Kalu O, Osuchukwu Nelson C. Prevalence of contraceptive use among women of reproductive age in Calabar Metropolis, Southern Nigeria. IJHSSI. 2013;2(6):27-34.

39. Rutaremwa G, Kabagenyi A, Wandera SO, et al. Predictors of modern contraceptive use during the postpartum period among women in Uganda: a population- based cross sectional study. BMC Public Health. 2015;15:262. doi:10.1186/s12889-015$1611-\mathrm{y}$

40. Dias JG, De Oliveira IT, Zhang M. Multilevel effects of wealth on women's contraceptive use in Mozambique. PLoS One. 2015;10(3): e0121758. doi:10.1371/journal.pone.0121758

41. Nketiah-Amponsah E, Arthur E, Abuosi A. Correlates of contraceptive use among Ghanaian women of reproductive age (15-49 years). Afr J Reprod Health. 2012;16(3):154.

42. Rourke T, Thesis M, Project D. Association between sociodemographic factors and knowledge of contraceptive methods with contraceptive use among women of reproductive age: a crosssectional study using the 2013 Liberia DHS. 2015.
43. Adebowale SA, Adedini SA, Ibisomi LD, Palamuleni ME. Differential effect of wealth quintile on modern contraceptive use and fertility: evidence from Malawian women. BMC Womens Health. 2014;14:4.

44. Currie J. Healthy, wealthy and wise: socio economic status, poor health in childhood and human capital development. J Econ Lit. 2009;47(1):87-122. doi:10.1257/jel.47.1.87

45. Osmani AK, Reyer JA, Osmani AR, Hamajima N. Factors influencing contraceptive use among women in Afghanistan: secondary analysis of Afghanistan Health Survey 2012. J Med Sci. 2015;77:551-561.

46. Birhane A, Alemayehu M, Hadush Z, Medhanyie AA, Ahmed M, Mulugeta A. Factors influencing contraceptive use among women of reproductive age from the pastoralist communities of Afar, Ethiopia: a community-based cross-sectional study. Ethiop $J$ Health Dev. 2018;32(Speciallssue).

47. Tukue D, Gebremeskel TG, Gebremariam L, et al. Prevalence and determinants of modern contraceptive utilization among women in the reproductive age group in Edaga-hamus Town, Eastern zone, Tigray region, Ethiopia. PLoS One. 2017;15(3).
International Journal of Women's Health

\section{Publish your work in this journal}

The International Journal of Women's Health is an international, peerreviewed open-access journal publishing original research, reports, editorials, reviews and commentaries on all aspects of women's healthcare including gynecology, obstetrics, and breast cancer. The manuscript management system is completely online and includes a very quick and fair peer-review system, which is all easy to use. Visit http://www.dovepress.com/testimonials.php to read real quotes from published authors. 